\title{
DUBLIN RADIOCARBON DATES I
}

\author{
I. R. McAULAY and W. A. WATTS
}

Trinity College, Dublin

\section{INTRODUCTION}

A $\mathrm{C}^{14}$-dating installation was operated in the Physics Department, Trinity College, Dublin, from early 1958 until early 1960, by I. R. McAulay. Construction and testing of the apparatus had occupied 15 months previous to this. Material for dating was selected and pretreated by W. A. Watts, who also collected and submitted the samples and carried out pollen analyses except where the contrary is stated in the text. The project was a short-term one with two main aims; to obtain a few key archaeologic dates, particularly in the Neolithic, to help orientate chronologic discussion; and to test the validity of the pollen zonation for the post-Atlantic of Mitchell (1956).

Operation of the machine has already been described (Delaney and McAulay, 1959). Scintillation techniques were used. Sample to be dated was converted to methyl alcohol and mixed with a liquid scintillator. The scintillator cell was of fused silica, in the form of a cylinder of volume $50 \mathrm{ml}, 10 \mathrm{ml}$ of methanol being added to $40 \mathrm{ml}$ liquid scintillator. The scintillator cell was viewed by two photomultipliers working in coincidence. The background counting rate was reduced by massive screening and by pulse-height selection. Reference sample counting rate was $20.3 \pm 0.18$ counts $/ \mathrm{min}$. above a background of $13.6 \pm 0.11$ counts $/ \mathrm{min}$. For reference sample 120 -yr-old oak wood was used. Counting period was 17 hours. Some of the samples were counted more than once, as a check on the consistency of the machine's ranning, but limited time made it unpractical to adopt this as a standard prosedure for all samples. After the 1959 radiocarbon conference at Groningen, counts were carried out on the oxalic-acid reference sample issued by the $\mathrm{U}$. S. Bureau of Standards (NBS), taking 95\% of its activity to be the "recent standard." Our former reference sample had yielded a contemporary count rate lower by ca. $1 \%$ than the count rate from the oxalic acid. Our earliest datings (D-1, D-22, D-28 to D-32, D-34, D-46 and D-68 to D-70), most of which had already been published (Delaney and McAulay, 1959), are based on our old standard, the remainder are based on the new. The difference between the standards is, in any case, a small one and no substantial change of date would result from recalculating dates based on the former standard. Pretreatment was by successive boiling in acid, alkali and acid again, in the case of the archaeologic samples. Bog samples were untreated, in view of the evidence of Overbeck and others (1957) that no particular advantage was obtained by removing the humus fraction from raised-bog peat.

\section{ACKNOWLEDGMENTS}

Our work was financed by the Royal Irish Academy, the Wenner-Gren Foundation, and Trinity Trusts (Trinity College, Dublin). We wish to thank these bodies for their support. We also wish to thank those Irish botanists and 
archaeologists who kindly helped us with samples and discussion. We thank particularly G. F. Mitchell, Trinity College, Dublin, F. M. Synge, Geological Survey of Ireland, and G. D. Liversage, Queen's University, Belfast, who gave much assistance during the most arduous part of the field work, collecting bog monoliths. We are indebted to G. F. Mitchell whose energy and enthusiasm for the project made it practicable in the first place.

Note: A detailed account of all the dates quoted here, together with the pollen diagrams referred to, will be offered to Proceedings of the Royal Irish Academy for publication during 1961.

\section{SAMPLE DESCRIPTIONS}

\section{POLLEN-DATED BOG SAMPLES}

The datings were made to test the scheme for pollen zoning the postAtlantic period suggested by Mitchell (1956), with some minor modifications proposed by Watts (1961). The zone boundaries proposed are as follows:zone VII (Atlantic)-VIII (Pagan) boundary, drawn where Ulmus (elm) curve falls suddenly in pollen diagrams and/or pollen of Plantago lanceolata (plantain) appears in quantities greater than single grains; zone VIII-IX (Christian period) boundary, drawn where Ulmus virtually disappears from pollen diagrams and Fraxinus (ash) suffers a simultaneous great decrease; zone IX-X (Afforestation period), dated historically to about A.D. 1700, when planting of exotic trees became widespread in Ireland. The appearance of their pollen, especially Pinus (pine) and Fagus (beech), in pollen diagrams defines the zone boundary. Suggested subdivisions of zone VIII are (1) at the first appearance of Fraxinus pollen in quantity early in the zone, (2) at the maximum value of Quercus (oak) reached in the middle of the zone, and (3) at a point where Fraxinus doubles its values late in the zone. Zone IX might be subdivided by (1) the rather sudden appearance of Artemisia (mugwort) pollen in abundance early in the zone, and (2) a conspicuous minimum for Corylus (hazel) which occurs slightly later. Boundaries were tested by dating slices of peat $2 \mathrm{~cm}$ thick from pollen-dated peat monoliths from raised bogs. Prominent recurrence surfaces in the bogs were also dated.

\section{Redbog series}

Peat samples from Redbog, County Louth $153^{\circ} 58^{\prime} \mathrm{N}$ Lat, $6^{\circ} 25^{\prime} \mathrm{W}$ Long). Monolith coll. 1958 by W. A. Watts and G. F. Mitchell, Trinity College, Dublin.

\section{D-1. Redbog, 406 to $408 \mathrm{~cm}$ depth}

$6460 \pm 200$

2 -cm slice of Dryopteris thelypteris peat, very humified. Sample dates zone VIb-VIc boundary, sensu Jessen (1949).

D-2. Redbog, 366 to $368 \mathrm{~cm}$ depth

$6400 \pm 200$

$2-\mathrm{cm}$ slice of wood peat rich in wood of Pinus (pine) and Betula (birch). Sample dates zone VIC-VII boundary, sensu Jessen (1949). Compare Q-166, $6955 \pm 131$ (Cambridge I) which lies just above same boundary.

\section{D-4. Redbog, 284 to $286 \mathrm{~cm}$ depth}


2-cm slice of Sphagnum-Calluna peat, rich in Eriophorum fibre. Sample lies at beginning of Ulmus fall. Zone VII.VIII boundary is placed at $280 \mathrm{~cm}$ where Ulmus falls to its lowest level before beginning to recover.

D-5. Redbog, 264 to $266 \mathrm{~cm}$ depth

$4430 \pm 140$

2-cm slice of very humified Sphagnum-Calluna peat, rich in Eriophorum fibre. Sample lies at rise of Ulmus to abundance once more after its first fall.

D-3. Redbog, 239 to $241 \mathrm{~cm}$ depth

$3570 \pm 170$

2 -cm slice of very humified Sphagnum-Calluna peat rich in Eriophorum fibre. Sample lies at first appearance of Fraxinus with moderate abundance. In interpreting the pollen diagram there was some doubt as to whether this slice should not be taken at $250 \mathrm{~cm}$, which would have yielded a date ca. 2000 B.C.

D-6. Redbog, 174 to $176 \mathrm{~cm}$ depth

$2625 \pm 130$

$2-\mathrm{cm}$ slice of moderately humified Sphagnum-rich peat with lenses of fresh Sphagnum. Sample lies at highest value for Quercus pollen in middle of zone VIII.

D-7. Redbog, 109 to $111 \mathrm{~cm}$ depth

$2220 \pm 130$

2-cm slice of moderately humified Sphagnum-rich peat with lenses of fresh Sphagnum. Sample marks the point high in zone VIII where Fraxinus increases greatly in abundance.

D-8. Redbog, 69 to $71 \mathrm{~cm}$ depth

$1725 \pm 130$ boundary.

2-cm slice of moderately humified Sphagnum peat. Sample dates VIII-IX

D-9. Redbog, 61 to $63 \mathrm{~cm}$ depth

$1380 \pm 120$

2 -cm slice of fresh Sphagnum peat from immediately above well-marked recurrence surface.

D-10. Redbog, 49 to $51 \mathrm{~cm}$ depth

$1450 \pm 130$

$2-\mathrm{cm}$ slice of fresh Sphagnum peat. Dates appearance of Artemisia in abundance early in time of zone IX.

D-11. Redbog, 27 to $29 \mathrm{~cm}$ depth

$500 \pm 130$

2-cm slice of fresh Sphagnum peat. Dates a small peak in Ulmus curve lying midway between the Corylus minimum at $40 \mathrm{~cm}$ and the beginning of zone $\mathrm{X}$ at $8 \mathrm{~cm}$.

D-12. Lomeloon Townland, County Sligo

$5160 \pm 190$

2 -cm slice of highly-humified Sphagnum peat at depth 14 to $16 \mathrm{~cm}$, from a short monolith obtained from peat exposed by drainage operations at Lough Gara, County Sligo ( $53^{\circ} 56^{\prime} \mathrm{N}$ Lat, $8^{\circ} 27^{\prime} \mathrm{W}$ Long). The peat represents basal remains of a destroyed raised bog. The slice dates the VII-VIII boundary. Coll. June 1958 by W. A. Watts and G. F. Mitchell, Trinity College, Dublin.

\section{Treanscrabbagh Townland series}

Samples from two peat monoliths from a large raised bog in this town- 
land, County Sligo ( $54^{\circ} 3^{\prime} \mathrm{N}$ Lat, $8^{\circ} 23^{\prime} \mathrm{W}$ Long). Coll. May 1958 by W. A. Watts and F. M. Synge, Geol. Survey of Ireland, Dublin.

D-13. Treanscrabbagh 1,386 to $388 \mathrm{~cm}$ depth $4970 \pm 190$

2 -cm slice of very homogeneous fen mud peat with much fibre, probably of Carices. Menyanthes and mosses abundant. Fragments of wood, Corylus nuts and Salix atrocinerea leaves occur. Sample dates VII-VIII boundary.

D-14. Treanscrabbagh 1,342 to $344 \mathrm{~cm}$ depth $4550 \pm 180$

2-cm slice of peat, similar to D-13. Dates first appearance of Fraxinus in quantity. A hearth of burnt stone and ash, but with no other finds, is buried in the bog at this level.

D-15. Treanscrabbagh 1,294 to $296 \mathrm{~cm}$ depth $3665 \pm 130$

2-cm slice of peat, similar to D-13. Dates maximum of Quercus in middle of zone VIII.

D-17. Treanscrabbagh 1,89 to $91 \mathrm{~cm}$ depth $1220 \pm 120$

$2 \cdot \mathrm{cm}$ slice of fresh Sphagnum peat with Calluna and Eriophorum. Dates appearance of Artemisia in quantity. There is a very striking recurrence surface at $98 \mathrm{~cm}$ and the zone VIIII-IX boundary lies at $108 \mathrm{~cm}$.

D-16. Treanscrabbagh 2,36 to $38 \mathrm{~cm}$ depth $3120 \pm 120$

$2-\mathrm{cm}$ slice of yellow-brown moss peat. Dates point in zone VIII where the sediment passes from moss peat with twigs and leaves to thick Eriophorum peat.

D-25. Tullymackan Townland, 106 to $108 \mathrm{~cm}$ depth $2030 \pm 130$

$2-\mathrm{cm}$ slice of very humified peat with twigs of Calluna from a peat monolith in a small raised bog in this townland, County Clare $\left(52^{\circ} 59^{\prime} \mathrm{N} \mathrm{Lat,} 8^{\circ}\right.$ $55^{\prime}$ W Long). Sample dates the doubling of Fraxinus values late in zone IX.

D-26. Clonsast trackway

$1910 \pm 130$

Corylus wood from a small, poorly-constructed trackway at the SW margin of this very large raised bog $\left(53^{\circ} 13^{\prime} \mathrm{N}\right.$ Lat, $7^{\circ} 13^{\prime} \mathrm{W}$ Long $)$. The trackway underlies Pinus stump layer described by Mitchell (1956, p. 202). This layer (dated by D-29, $1620 \pm 130$, this date list), in turn immediately underlies the VIII-IX boundary. Coll. and subm. December 1958 by Dr. N. Murray, Trinity College, Dublin. Pollen diagrams in Murray (1957).

\section{D-29. Clonsast stump}

$1620 \pm 130$

Pinus root wood from horizon of Pinus stumps growing on a recurrence surface at the SW corner of the bog. Stump layer lies from 65 to $75 \mathrm{~cm}$ below bog surface, from which top few $\mathrm{cm}$ have been removed. Parts of same root have been dated by Yale (Y-94, $1610 \pm 80$, Yale III) and by Groningen (Gro-271, $1485 \pm 150$; Groningen dates in this paper, which are not corrected for the Suess effect, are quoted from Mitchell (1958). The trees, some of which reached an age of about $100 \mathrm{yr}$, must have been growing ca. A.D. 300 . VIII-IX boundary lies at $58 \mathrm{~cm}$ and must be slightly younger. Coll. 1953 
and subm. by G. F. Mitchell. Trinity College, Dublin. Pollen diagram in Mitchell (1956).

\section{Agher Townland series}

Samples from a small, much destroyed, raised bog in this townland, County Meath $\left(53^{\circ} 27^{\prime} \mathrm{N}\right.$ Lat, $6^{\circ} 45^{\prime} \mathrm{W}$ Long). Monolith coll. 1958 by W. A. Watts and G. F. Mitchell, Trinity College, Dublin.

D-18. Agher, 62 to $64 \mathrm{~cm}$ depth

$1610 \pm 120$

$2-\mathrm{cm}$ slice of very fresh Sphagnum peat. Sample dates VIII-IX boundary.

D-20. Agher, 23 to $25 \mathrm{~cm}$ depth

$1380 \pm 120$ IX.

2-cm slice of very fresh Sphagnum peat. Dates Corylus minimum early in

\section{D-21. Agher, $103 \mathrm{~cm}$ depth}

$1650 \pm 120$

Thin slice of very humified greasy amorphous peat lying immediately below a marked recurrence surface.

\section{D-22. Agher, $101 \mathrm{~cm}$ depth}

$1200 \pm 120$

Thin slice of very fresh Sphagnum peat with leaves of Andromeda and Oxycoccus representing flooding of humified peat surface dated by D-21. General Comment: although separated by $40 \mathrm{~cm}$ of peat from D-18, there is probably not a very great age difference between D-18 and D-21, as the pollen diagram indicates very rapid bog growth at this stage. D-22, which should be of ca. the same age as D-21, appears to be too young.

\section{Fallahogy Townland series}

A raised bog in this townland, County Derry $\left(54^{\circ} 54^{\prime} \mathrm{N}\right.$ Lat, $6^{\circ} 33^{\prime} \mathrm{W}$ Long) has been investigated by A. G. Smith, Queen's Univ., Belfast (Smith, 1958). Samples are slices from a bog monolith coll. 1958 by Dr. Smith.

\section{D-23. Fallahogy Ulmus fall}

$3290 \pm 140$

2 -cm slice of Eriophorum peat with some Calluna. Corresponds to $285 \mathrm{~cm}$ level in Fallahogy Td. I pollen diagram (Smith, 1958). Sample dates zone VII-VIII boundary, sensu Mitchell (1956). Subm. 1958 by A. G. Smith, Queen's Univ., Belfast.

D-24. Fallahogy Fraxinus appearance

$$
3070 \pm 140
$$

2-cm slice of Eriophorum peat with some Calluna. Corresponds to $255 \mathrm{~cm}$ level in Fallahogy Td. I pollen diagram (Smith, 1958). Sample dates rise of Fraxinus low in zone VIII (Mitchell, 1956). General comment: Fallahogy dates are self-consistent but appear too young in comparison with those already obtained for these horizons. Sources of discrepancy may be (1) that a pollen zonation which works for the Irish Central Plain may not be applicable to other regions of Ireland, (2) there may have been a technical error, though both datings were repeated with the same result, (3) the pollen diagram may have been misinterpreted. The Cambridge laboratory has agreed to recheck the dates and, pending this, further comment may be withheld. 


\section{General Comments on Pollen-Zone Datings}

D-4. D-12 and D-13 suggest that the VII-VIII boundary lies about 3000 B.c. This agrees with other dates for this horizon, e.g. Q-171, $4932 \pm 134$ (Cambridge I). The VIIII-IX boundary proposed by Mitchell (1956) seems well-founded at about A.D. 300. This is important, because this boundary is based on sharply-defined, easily-recognized features and is most valuable in subdividing the post-Atlantic. The Quercus maximum, which Mitchell used to subdivide zone VIII, is evidently unsuitable for the purpose. Compare also Gro-272, 3400 \pm 170 (Mitchell, 1958) which dates this feature. The first appearance of Fraxinus in zone VIII in quantity D-3, $3570 \pm 170$, D-14, 4550 \pm 180 , (this date list) and Y-93, 4170 \pm 80 (Yale III), which lies just after Fraxinus first appears, lies between 2500 and 2200 B.c., but as seen from the Redbog pollen diagram (see comment on D-3) it may be difficult to decide the exact point at which Fraxinus may be said to "appear in quantity". Evidently the appearance of Fraxinus is of considerable value for dating purposes, but is not suitable for defining a pollen zone. The doubling of Fraxinus values, which occurs high in zone VIII, appears to occur about 100 B.c. The point at which a great increase in Fraxinus is seen can be drawn sharply in some pollen diagrams, but not all. Therefore, this event has indicator value for age, but is not suitable as the basis of a zone boundary. The same observations apply to the appearance of Artemisia low in zone XI and the Corylus minimum which occurs slightly higher. The former increases its quantity about A.D. 600 ; the latter slightly later. Gro-651, $980 \pm 80$ (Mitchell, 1958) lies just above the Corylus minimum.

\section{MISCELLANEOUS BOG DATES}

\section{D-28. Treanmacmurtagh, County Sligo}

$\mathbf{3 6 7 0} \pm \mathbf{1 3 0}$

Charcoal from a hearth of burnt stone and ash without archaeologic finds, embedded in raised-bog peat of zone VIII in this townland $\left(54^{\circ} 3^{\prime} \mathrm{N}\right.$ Lat, $8^{\circ}$ 24' W Long). Coll. 1956 and subm. by G. F. Mitchell, Trinity College, Dublin.

\section{D-27. Timoney Bog, County Tipperary}

$\mathbf{5 5 0} \pm \mathbf{1 2 0}$

Bark and outer wood of Taxus (yew) stump bearing axe marks, buried $150 \mathrm{~cm}$ below bog surface in Timoney Townland $\left(52^{\circ} 55^{\prime} \mathrm{N}\right.$ Lat, $7^{\circ} 45^{\prime} \mathrm{W}$ Long). The stump dates an adjacent occupation site, $150 \mathrm{~cm}$ below the bog surface, marked by a floor of sandstone slabs covered by ashes and by two large wooden troughs. The site is unique in that the bog seems to have been severely eroded at one period; then the surface of the eroded peat was occupied; then the peat re-formed. More detailed archaeologic and pollen-analytical work is still necessary. Coll. February 1959 by W. A. Watts and N. Murray at site indicated by A. Lucas, National Museum, Dublin.

D-30. Beaghmore, County Tyrone

$1400 \pm 120$

At Beaghmore Townland ( $54^{\circ} 42^{\prime} \mathrm{N}$ Lat, $6^{\circ} 57^{\prime} \mathrm{W}$ Long) stone circles, stone alignments and old field boundaries are buried by blanket peat. Sample dates the base of the peat. Site is described by May (1953). A pollen diagram was prepared from the peat by G. F. Mitchell (May, 1953, p. 194) but was 
uninformative. Comment: peat date can only provide a terminus ante quem for the site which, on archaeologic grounds, must be much older. A. G. Smith, Queen's Univ., Belfast, is re-investigating the site.

\section{D-31. Sutton, County Dublin}

$3730 \pm 130$

Estuarine peat $\left(53^{\circ} 23^{\prime} \mathrm{N}\right.$ Lat, $6^{\circ} 6^{\prime} \mathrm{W}$ Long) exposed under marine gravels at ca. $6 \mathrm{~m}$ above o.D. Gravels represent a retreat stage of marine transgression which had reached its maximum before 3000 B.c., in the Irish Sea area. See Q-120, 5412 \pm 130 (Cambridge I) which dates maximum of transgression.

\section{D-32. Ballynaclash Townland, County Wexford $\quad 11,060 \pm 250$}

In this townland $\left(52^{\circ} 25^{\prime} \mathrm{N}\right.$ Lat, $6^{\circ} 20^{\prime} \mathrm{W}$ Long) black algal mud $3 \mathrm{~cm}$ thick, and covered by clay-rich peat $12 \mathrm{~cm}$ thick, is exposed on the seashore. The deposit is overlain by $2 \mathrm{~m}$ of sand with clay lenses and small stones. It lies in a hummocky area, rich in kettles, which marks the end moraine of the last glaciation. Coll. March 1958 by W. A. Watts and F. M. Synge, Geol. Survey, Dublin. Comment: in spite of the surprisingly thick overburden the algal mud, which was used for dating, is obviously of Allerød age, agreeing with the numerous Allerød dates already published, e.g. in Cambridge I. The pollen diagram supports the date.

\section{ARCHAEOLOGIC SAMPLES}

Samples D-36 to D-49 and D-51 have already been published and discussed, (Watts, 1960) and will be treated briefly here.

\section{D-36. Newferry, County Antrim}

Charcoal from hearth $\left(54^{\circ} 49^{\prime} \mathrm{N}\right.$ Lat, $6^{\circ} 27^{\prime} \mathrm{W}$ Long $)$, containing Bann flakes and fragments of polished stone axes stratified in diatomite. Pretreatment: the charcoal, which was silicified, was reboiled in HF. Coll. August 1959 by W. A. Watts and G. D. Liversage, at site indicated by A. G. Smith, Queen's Univ., Belfast. Site description in Movius (1942).

\section{D-37. Knockiveagh, County Down}

Charcoal from beneath large stone cairn $\left(54^{\circ} 17^{\prime} \mathrm{N}\right.$ Lat, $6^{\circ} 10^{\prime} \mathrm{W}$ Long). Charcoal was mixed with abundant sherds of Neolithic pottery. Site excavated and published by Collins (1957). Coll. 1956 and subm. by A. P. Collins, Archaeological Survey of North Ireland, Belfast.

\section{D-38. Dalkey Island, County Dublin}

$\mathbf{5 3 0 0} \pm \mathbf{1 7 0}$

Charcoal from shell midden $\left(53^{\circ} 17^{\prime} \mathrm{N}\right.$ Lat, $6^{\circ} 5^{\prime} \mathrm{W}$ Long) where finds suggest a transition from Mesolithic to Neolithic economy. Coll. and subm. 1959 by the excavator, G. D. Liversage, Queen's Univ., Belfast. Site not yet published. Comment: D-36, D-37 and D-38 suggest that the Neolithic in Ireland began before 3000 B.c. This is supported by other dates, e.g. BM-73, $4910 \pm$ 150 (Smith, 1960).

\section{D-39. Geroid Island, Lough Gur, County Limerick $4090 \pm 140$}

Charcoal from habitation site $\left(52^{\circ} 30^{\prime} \mathrm{N}\right.$ Lat, $8^{\circ} 32^{\prime} \mathrm{W}$ Long $)$ associated 
with Neolithic pottery. Described by Liversage (1958). Subm. 1959 by G. D. Liversage, Queen's Univ., Belfast.

D-34. Geroid Island, Lough Gur, County Limerick $3680 \pm 140$

Wood from Quercus stump overlying habitation layer described in D-39. Gives a terminus ante quem for the Neolithic occupation of the island. Consistent with D-39. Published as T.C.D./8 in Liversage (1958). Subm. 1958 by G. D. Liversage, Queen's College, Belfast.

D-40. Circle L, Knockadoon, Lough Gur

$4410 \pm 240$

Charcoal from Neolithic house site $\left(52^{\circ} 32^{\prime} \mathrm{N}\right.$ Lat, $8^{\circ} 32^{\prime} \mathrm{W}$ Long). Dates early phase of Knockadoon occupation. Unpublished excavation, 1954, by late S. P. O'Riordain. Subm. 1959 by M. de Paor, University College, Dublin. Other similar sites at Knockadoon are described by O'Riordain (1954).

D-41. Circle L, Knockadoon, Lough Gur

Charcoal from posthole of house dated by D-40. Comment: D. 40 and D-4.1 have large errors, due to the small quantities of charcoal available. Dates may be combined to give a date of ca. 2600 B.c. for the house.

D-42. Mound of the Hostages, Tara, County Meath $4080 \pm 160$ Charcoal infilling of a ditch $\left(53^{\circ} 35^{\prime} \mathrm{N}\right.$ Lat, $6^{\circ} 37^{\prime} \mathrm{W}$ Long), predating a passage grave of the Boyne culture. Coll. 1959 by W. A. Watts on behalf of the excavator, R. de Valera, University College, Dublin. Excavation not yet published.

D-43. Mound of the Hostages, Tara, County Meath $4260 \pm 160$ Fine charcoal fragments from burnt ground surface under stone cairn of Boyne culture passage grave. Details as D-42.

D-44. Mound of the Hostages, Tara, County Meath $3880 \pm 150$

Charcoal from fire on old ground surface of passage grave close to entry to the passage. Details as D-42.

D-45. Four Knocks 2, County Meath

$3480 \pm 140$

Charcoal $\left(53^{\circ} 35^{\prime} \mathrm{N}\right.$ Lat, $6^{\circ} 17^{\prime} \mathrm{W}$ Long) from a cremation pit containing Loughcrew pottery associated with a Boyne culture passage grave. Coll. 1950 by the excavator, P. J. Hartnett, Bord Failte Office, Dublin. Site mentioned in Hartnett (1957). Subm. 1958 by National Museum, Dublin. Comment: D-42 to D-45 suggest that Boyne culture dates ca. and shortly after 2000 B.C.

D-46. Goodland, County Antrim

$4150 \pm 200$

Very humified peat $\left(55^{\circ} 13^{\prime} \mathrm{N}\right.$ Lat, $6^{\circ} 7^{\prime} \mathrm{W}$ Long $)$, rich in Juncus seeds. Base of blanket bog overlying Neolithic ritual site. Coll. 1954 and subm. by the excavator, H. Case, Ashmolean Museum, Oxford. Publication pending in Proceedings of the Prehistoric Society.

D-47. Island MeHugh, County Tyrone $\quad 3380 \pm 120$ Charcoal $\left(7^{\circ} 25^{\prime} \mathrm{N}\right.$ Lat, $7^{\circ} 25^{\prime} \mathrm{W}$ Long) embedded in peat with late 
Neolithic pottery of Sandhill type. Coll. and subm. August 1959 by W. A. Watts, G. D. Liversage and G. Eogan, Trinity College, Dublin. Site excavated and published by Davies (1950). Samples came from a part of the site which had been left unexcavated.

\section{D-48. Ballyutoag, County Antrim}

$4120 \pm 300$

Charcoal $\left(54^{\circ} 39^{\prime} \mathrm{N}\right.$ Lat, $5^{\circ} 59^{\prime} \mathrm{W}$ Long) from the forecourt of horned cairn, associated with Neolithic pottery. Coll. 1935 by I. J. Herring, the excavator; subm. 1959 by Belfast Municipal Museum. Description of site in Herring (1938). Comment: small quantity of charcoal available makes a large error inevitable.

\section{D-49. Island, County Cork}

$3110 \pm 140$

Charcoal $\left(52^{\circ} 4^{\prime} \mathrm{N}\right.$ Lat, $8^{\circ} 35^{\prime} \mathrm{W}$ Long $)$ from around the bases of the orthostats of wedge-shaped gallery grave. Coll. 1957 and subm. by M. J. O'Kelly, University College, Cork (O'Kelly, 1958a). Comment: date is rather young on archaeologic grounds, but not impossible.

\section{D-50. Carn, County Mayo}

$3000 \pm 140$

Handle of halberd made of Quercus (oak) wood $\left(54^{\circ} 15^{\prime} \mathrm{N}\right.$ Lat, $9^{\circ} 19^{\prime}$ W Long) found in a bog in County Mayo in 1941. Subm. by J. Raftery, National Museum, Dublin (Raftery, 1942).

\section{D-51. Dundrum Sandhills, County Down}

$2860 \pm 140$

Charcoal $\left(54^{\circ} 14^{\prime} \mathrm{N}\right.$ Lat. $5^{\circ} 50^{\prime} \mathrm{W}$ Long) associated with Neolithic pot. tery forming an occupation horizon huried in dune sand. Coll. and subm. 1959 by A. P. Collins, Archaeological Survey of N Ireland, Belfast. Comment: date is too young. The error may lie in the difficulty associated with sand-dune sites. that material from several horizons may become mixed due to erosion of the dunes and sand movement.

\section{D-52. Shanballyedmond, County Tipperary}

$2050 \pm 130$

Charcoal $\left(52^{\circ} 41^{\prime}\right.$ N Lat. $8^{\circ} 14^{\prime}$ W Long) from chamber of a horned cairn. Coll. and subm. 1958 hy M. J. O'Kelly, Iniversity College, Cork. Site is described in O'Kelly (1958h). Comment: there was some doubt as to whether this charcoal was in primary position. Clearly it was not, for the date is far too young.

\section{Lough Gara series}

During 1955, Dr. J. Raftery, National Museum, Dublin, excavated "Crannog 61", one of a large group of artificial islands constructed as house sites which came to light as the water level of the lake fell due to drainage operations. The crannog $\left(53^{\circ} 56^{\prime} \mathrm{N}\right.$ Lat, $8^{\circ} 25^{\prime} \mathrm{W}$ Long) had occupation layers dating from the Late Bronze Age and Early Iron Age and gave an opportunity to date the transition between the two. Material subm. by National Museum, Dublin. Site has not yet been published.

D-53. Lough Gara S. 176

Corylus twigs from fire basket. Late Bronze Age horizon.

$2070 \pm 130$ 
D-54. Lough Gara S. 172

$2140 \pm 130$

Corylus twigs from fire basket. End of Late Bronze Age. Sample should be slightly younger than D-53.

D-55. Lough Gara S. 177

$2150 \pm 130$

Wood from the outermost circle of crannog piles. No archaeologic evidence of age.

D-56. Lough Gara S. 174

$310 \pm 120$

Wood from piles forming ultimate structure of crannog. Comment: Dr. Raftery suggests a date ca. A.D. 400 for this structure, but it appears to be much later.

D-57. Lough Gara S. 171

$2100 \pm 130$

House posts of Quercus (oak) wood from the early Iron Age period.

D-58. Lough Gara S. 173

$1630 \pm 130$

Wood from outer revetment piles of crannog. Early Iron Age period.

D-59. Lough Gara S. 175

$2150 \pm 130$

Corylus twigs from fire basket. Late Bronze Age level. Should be of the same age as D-53, which comes from same horizon.

D-60. Lough Gara cereals

$$
2160 \pm 130
$$

Charred cereals. End of Late Bronze Age horizons. Should be more or less contemporary with D-54.

D-61. Lough Gara S. 39

$2250 \pm 130$

Charcoal from clay near hase of hearth under a large stone mass. Should he of Early Iron Age date. General comment: Lough Cara dates suggest that the crannog was constructed not earlier than 250 B.c. and was occupied until the early centuries A.D. Most archaeologists would think 250 B.c. a rather young date for the Late Bronze Age-Early Iron Age transition.

\section{Drombeg Townland series}

In this townland, County Cork $\left(51^{\circ} 34^{\prime} \mathrm{N}\right.$ Lat, $9^{\circ} 5^{\prime} \mathrm{W}$ Long) E. M. Fahy, Cork Public Museum, excavated a stone circle in 1958. Associated with the circle were a pit containing some pottery and an ancient cooking pit. Samples subm. by E. M. Fahy. Site is described in Fahy (1959).

D-62. Drombeg stone circle

$1350 \pm 120$

Charcoal associated with fragments of pottery in a soil-filled pit. The pottery was thought by the excavator to resemble Lough Gur Class 2 ware and would therefore be late Neolithic. This sample is described as T.C.D. 38 in Fahy (1959).

D-63. Drombeg cooking pit

$1390 \pm 120$

Charcoal from old ground surface of cooking pit.

D-64. Drombeg cooking pit

$1520 \pm 120$

Charcoal from base of cooking pit. General comment: both the pottery and the cooking pit date to about A.D. 500. The three dates agree so well that a 
Neolithic date seems impossible. Whether stone circles of the Drombeg type, "recumbent stone circles", may also be of this age is still an open question. It is possible that there were two periods of occupation at the site.

D-65. Drumaroad, County Down

$900 \pm 120$

Charcoal $\left(54^{\circ} 18^{\prime} \mathrm{N} \mathrm{Lat}, 5^{\circ} 54^{\prime} \mathrm{W}\right.$ Long) from a house site within a cashel (stone-built fort). Sample dates pottery of "souterrain ware" type associated with the house. Coll. 1953 and subm. by D. M. Waterman, Archaeological Survey of N Ireland, Belfast. Published by Waterman (1956).

\section{D-66. Larne, County Antrim}

$1470 \pm 120$

Charcoal (54. $55^{\prime} \mathrm{N}$ Lat, $5^{\circ} 51^{\prime} \mathrm{W}$ Long) associated with "souterrain ware". Coll. 1957 and subm. by D. M. Waterman, Archaeological Survey of N Ireland. Publication: preliminary note (Anonymous, 1958). Comment: (D-65 and D-66) "souterrain ware" is associated in N Ireland with Early Christian stone- or earth-built habitation sites (cashels and raths respectively). Dates agree well with the archaeologic expectation.

D-68. Milmorane, County Cork

$4040 \pm 150$

Blanket bog peat $\left(51^{\circ} 52^{\prime} \mathrm{N}\right.$ Lat, $9^{\circ} 12^{\prime} \mathrm{W}$ Long $)$ surrounding a necklace which, on archaeologic grounds, should be of Iron Age date. Coll. 1944 and subm. by G. F. Mitchell, Trinity College, Dublin. A pollen diagram of the site is available (Mitchell, 1951). Comment: pollen diagram and radiocarbon dates agree. Evidently the necklace was buried in the bog.

\section{D-69. Ballingarry Downs}

$1200 \pm 120$

Charcoal $\left(52^{\circ} 23^{\prime} \mathrm{N} \mathrm{Lat}, 8^{\circ} 2 \mathrm{l}^{\prime} \mathrm{W}\right.$ Long $)$ from occupation debris of a large ring fort from this townland near Ballylanders, County Limerick. Excavated by J. Hunt, 1955. Subm. by G. F. Mitchell, Trinity College, Dublin. Photograph in O'Riordain (1953). The excavation is unpublished.

\section{D-67. Garryduff, County Cork}

$250 \pm 120$

Charcoal $\left(52^{\circ} 1^{\prime} \mathrm{N}\right.$ Lat, $8^{\circ} 7^{\prime} \mathrm{W}$ Long) from occupation debris of a ring fort in this townland. Site was rich in finds suggesting a date in the middle of the first millennium A.D. Coll. 1945 and subm. by M. J. O'Kelly, University College, Cork. Preliminary note of excavation in O'Kelly (1946). Comment: the charcoal is a secondary intrusion.

\section{CHECK SAMPLE}

\section{D-70. Nabu Temple, Nimrud, Iraq}

$2506 \pm 140$

Charred wood from Nabu Temple at ancient Nimrud $\left(36^{\circ} 11^{\prime} \mathrm{N}\right.$ Lat, $43^{\circ}$ $20^{\prime}$ E Long). Coll. 1956 by M. E. L. Mallowan, Univ. of London. Archaeologic date of the specimen should be some decades before 612 в.c. Comment: sample has also been dated by the British Museum at $2400 \pm 150$ (BM-59), (British Museum II). Date quoted above was obtained, using our old reference standard. A second dating, using the oxalic-acid standard, gives $2730 \pm 120$. 


\section{MISCELLANEOUS SAMPLE}

D-71. Kentmere boat

Wood from remains of a boat discovered at Kentmere, Westmoreland $\left(54^{\circ} 26^{\prime} \mathrm{N}\right.$ Lat, $2^{\circ} 21^{\prime} \mathrm{W}$ Long). Sample dated at suggestion of British Museum laboratory. Comment: age of boat was in doubt. Possibilities seemed to be either early centuries A.D., or much later. The latter view appears correct.

Date lists:

British Museum II Barker and Mackey, 1950

Cambridge I Godwin and Willis, 1959

Yale III Barendson, Deevey and Gralenski, 1957

Anonymous, 1958, Ballygalley Hill, Co. Antrim: Prehist. Soc. Proc., v. 24, p. 218.

Barendsen, G. W., Deevey, E. S. and Gralenski, L. J., 1957, Yale natural radiocarbon measurements III: Science, v. 126, p. 908-919.

Barker, H. and Mackey, C. J., 1960, British Museum natural radiocarbon measurements II: Am. Jour. Sci. Radioc. Supp., v. 2, p. 26-30.

Collins, A. P., 1952, Excavations in sandhills at Dundrum, Co. Down, 1950-51: Ulster Jour. Archaeology, v. 15, p. 2-26

1957, Trial excavations in a round cairn on Knockiveagh, Co. Down: Ulster Jour. Archaeology, v. 20, p. 8-28.

Davies, O. 1950, Excavations at Island McHugh: Belfast, Belfast Nat. History and Philos. Soc., [special publication], $124 \mathrm{p}$.

Delaney, C. F. G., and McAulay, I. R., 1959, A radiocarbon dating system using scintillation techniques: Royal Dublin Soc. Sci. Proc., ser. A, v. 1, p. 1-20.

Fahy E M. 1959 A recumbent-stone circle at Drombeg, Co. Cork: Cork Hist. and Archaeol. Soc. Jour., v. 64, p. 1-27.

Godwin, H., and Willis, E. H., 1959, Cambridge University natural radiocarbon measurements I: Am. Jour. Sci. Radioc. Supp., v. 1, p. 63-75.

Hartnett, P. J. 1957, Excavation of a passage-grave at Four Knocks, Co. Meath: Royal Irish Acad. Proc., ser. C, v. 58, p. 197-277.

Herring, I. J., 1938, The forecourt, Hanging Thorn Cairn, Ballyutoag, Ligoniel: Belfast Nat. Hist. and Philos. Soc. Proc., v. 5, p. 43-49.

Jessen, K., 1949, Studies in late quaternary deposits and flora history of Ireland: Royal Irish Acad. Proc., v. 52, ser. B, p. 88-290.

Liversage, G. D., 1958, An island site at Lough Gur: J.R.S.A.I., v. 88, p. 67-81.

May A McL. 1953, Neolithic habitation site, stone circles and alignments at Beaghmore, Co. Tyrone: J.R.S.A.I., v. 83, p. 174-197.

Mitchell, G. F., 1951, Studies in Irish quaternary deposits, No. 7: Royal Irish Acad. Proc., ser. B, v. 53, p. 111-206.

1956, Post-Boreal pollen-diagrams from Irish raised bogs: Royal Irish Acad. Proc., ser. B, v. 57 , p. $185-251$.

56.

Movius, H. L., Jr., 1942, The Irish stone age, Cambridge, its chronology, development, and relationships: Cambridge, Cambridge Univ. Press, $339 \mathrm{p}$.

Murray, N., 1957, Evidence of former tree growth at Clonsast: [Unpub. Ph.D. thesis], Trinity College, Dublin.

O'Kelly M. J., 1946, Excavation of a ring-fort at Garryduff, Co. Cork: Antiquity, v. 20, p. $122-126$. p. $1-24$. 1958b, A horned-cairn at Shanballyedmond, Co. Tipperary: Cork Hist. and Archaeol. Soc. Jour., v. 63, p. 37-72.

O'Riordain, S. P., 1953, Antiquities of the Irish countryside, 3rd ed.: London, Methuen. 1954, Lough Gur excavations: Neolithic and Bronze houses on Knockadoon: Royal Irish Acad. Proc., ser. C, v. 56, p. 297-459.

Overbeck, F Münnich, K, O. Aletsee, L., and Averdieck, F. R., 1957, Das Alter des "Grenzhorizonts" norddeutscher Hochmoore nach Radiocarbon-Datierungen: Flora, v. 145 , p. $37-71$. 
Raftery, J., 1942, A bronze halberd from Carn, Co. Mayo: Galway Archaeol. and Hist. Soc. Jour., v. 20 , p. $54-56$.

Smith, A. G., 1958, Pollen-analytical investigations of the mire at Fallahogy Td., Co. Derry: Royal Irish Acad. Proc., ser. B, v. 59, p. 329-343.

Smith, I., 1960, Radio-carbon dates from Windmill Hill: Antiquity, v. 34, p. 212-213.

Waterman, D. M., 1956, The excavation of a house and souterrain at White Fort, Drumaroad, Co. Down: Ulster Jour. Archaeology, v. 19, p. 73-86.

Watts, W. A., 1960, C-14 dating and the Neolithic in Ireland: Antiquity, v. 34, p. 111. 33-38. 